\title{
Effect of Polyoxin D on Achlya radiosa
}

\author{
By SONIA M. C. DIETRICH AND GALBA M. A. CAMPOS \\ Instituto de Botânica, Caixa Postal 4005, São Paulo, SP, Brazil
}

(Received 3 October 1977)

\section{INTRODUCTION}

The oomycetes have been characterized by the presence of cellulose and absence of chitin in their cell walls (Aronson, 1965; Bartnicki-Garcia, 1968; Dick, 1969). Recently, however, the presence of chitin was unequivocally shown in the oomycete Apodachlya, order Leptomitales (Lin \& Aronson, 1970; Lin, Sicher \& Aronson, 1976). Some evidence was also obtained for its presence in 10 isolates belonging to the orders Saprolegniales and Peronosporales (Dietrich, 1973, 1975), by the production of $N$-acetylglucosamine from the walls after treatment with a chitinase-enriched snail digestive juice preparation. However, the latter results have been questioned (Lin et al., 1976) on the grounds that the enzyme preparation used might contain enzymes capable of liberating $N$-acetylglucosamine from substrates other than chitin.

Since it has been proposed that differences in the amounts of the presumed chitinous compound in the walls of oomycetes are important in the phylogeny of this group of fungi (Dietrich, 1973, 1975), further evidence regarding its chemical nature is needed.

Polyoxin D is a specific inhibitor of chitin synthase (Endo, Kakiki \& Misato, 1970) and it has been used to investigate the presence and role of chitin in different fungi (Keller \& Cabib, 1971; Bartnicki-Garcia \& Lippman, 1972; Gooday, 1972). In this paper we report the effect of polyoxin D on the oomycete Achlya radiosa.

\section{METHODS}

Chemicals. Polyoxin D was a kind gift from Dr Saburo Suzuki (Rikagaku Kenkuysho, Japan). The antibiotic migrated as a single component in the chromatography system described by Isono et al. (1967) and had the same $R_{F}$ as a pure sample of polyoxin D provided by Dr Nobuo Sazaki (Haken Chemical Co., Japan). [G- $\left.{ }^{14} \mathrm{C}\right]$ Glucose $\left(66 \mathrm{mCi} \mathrm{mM}^{-1}\right)$ was from the Départment de Biologie, CEA, France; $N-\left[1-{ }^{14} \mathrm{C}\right]-$ acetyl-D-glucosamine $\left(\left[{ }^{4} \mathrm{C}\right] \mathrm{GlcNAc} ; 5.0 \mathrm{mCi} \mathrm{m}^{-1}\right)$ was from $\mathrm{ICN}$ Isotope \& Nuclear Division, California, U.S.A.

Organism and culture methods. Achlya radiosa Maurizio, strain SPC30 (= Achlya pseudoradiosa Rogers \& Benecke) was from the live collection of the Instituto de Botânica de São Paulo. It was maintained and grown in Seymour's MSPS agar medium (Seymour, 1970). Discs of inoculum were transferred either to the centre of Petri dishes of the same medium or to $125 \mathrm{ml}$ Erlenmeyer flasks containing $50 \mathrm{ml}$ of Seymour's MSPS liquid medium (Seymour, 1970). Polyoxin D and other compounds to be added were sterilized separately by membrane filtration (Millipore filters) and mixed with the autoclaved media at 50 to $60{ }^{\circ} \mathrm{C}$. The media were prepared to give the same final concentrations of constituents after the additions. Cultures were incubated at $22^{\circ} \mathrm{C}$ in the dark, without agitation.

Growth measurements. Experiments were carried out with three replicates per treatment. The diameter of agar-grown cultures was measured daily to the nearest millimetre, the diameter of the original inoculum being subtracted. For experiments in liquid medium, the cultures were harvested by centrifugation at $1000 \mathrm{~g}$ for $20 \mathrm{~min}$ in the cold and washed by centrifugation in cold distilled water three times. The washed mycelia were freeze-dried and weighed, the dry weight of the initial inoculum (mean of 10 discs) being subtracted.

Colonies of $A$. radiosa on agar plates and on agar-coated slides were used to examine the effects of polyoxin $\mathrm{D}$ on hyphal morphology. The plates and slides were prepared with the same medium as used for growth analysis. The slides were covered with coverglasses; the inoculum was placed on the periphery of the coverglass and the whole system was maintained in a moist atmosphere during the growth period. Polyoxin D 
Table 1. Effect of polyoxin $D$ on growth and wall composition in $A$. radiosa

\begin{tabular}{|c|c|c|c|c|}
\hline \multirow[b]{2}{*}{ Treatment } & \multirow[b]{2}{*}{$\begin{array}{c}\text { Hyphal diameter* } \\
\pm \text { S.D. }(\mu \mathrm{m})\end{array}$} & \multirow[b]{2}{*}{$\begin{array}{c}\text { Mycelial } \\
\text { dry wt } \dagger \\
\pm \text { s.D. (mg) }\end{array}$} & \multicolumn{2}{|c|}{$\begin{array}{l}\text { Wall composition } \ddagger \\
(\%, w / w, \text { of total })\end{array}$} \\
\hline & & & $\begin{array}{l}\text { Reducing } \\
\text { sugars }\end{array}$ & Hexosamines \\
\hline $\begin{array}{l}\text { Control } \\
+ \text { Polyoxin D } \\
\quad\left(100 \mu \mathrm{g} \mathrm{ml}^{-1}\right)\end{array}$ & $\begin{array}{l}19 \cdot 7 \pm 2 \cdot 2 \\
24 \cdot 9 \pm 3 \cdot 0\end{array}$ & $\begin{array}{l}18 \cdot 2 \pm 1 \cdot 8 \\
23 \cdot 2 \pm 2 \cdot 2\end{array}$ & $\begin{array}{l}64 \cdot 8 \\
68 \cdot 4\end{array}$ & $\begin{array}{l}2 \cdot 7 \\
1 \cdot 3\end{array}$ \\
\hline $\begin{array}{l}\text { Inhibition } \\
\text { by polyoxin } \mathrm{D}(\%)\end{array}$ & - & - & - & $51 \cdot 9$ \\
\hline
\end{tabular}

\section{Table 2. Effect of polyoxin D on $\left[{ }^{14} C\right] G l c N A c$ incorporation and GlcNAc content in walls of $A$. radiosa}

Mycelium was grown for $72 \mathrm{~h}$ in MSPS containing $\left.{ }^{14} \mathrm{C}\right] \mathrm{GIcNAc}$ with or without glucose in the presence of polyoxin $\mathrm{D}\left(100 \mu \mathrm{g} \mathrm{ml}^{-1}\right)$. Data are expressed as a percentage of the values obtained in controls grown under the same conditions but without polyoxin $\mathrm{D}$.

\begin{tabular}{lclcc} 
& $\begin{array}{c}\left.\text { Incorporation of }{ }^{14} \mathrm{C}\right] \mathrm{GlcNAc} \\
\text { (\% of control) }\end{array}$ & \multicolumn{2}{c}{$\begin{array}{c}\text { Wall GlcNAc content* } \\
\text { (\% of control) }\end{array}$} \\
Medium & $\overbrace{\text { Whole mycelium }}$ & Wall & $\overbrace{\left[{ }^{14} \mathrm{C}\right] \text { GlcNAc }}^{\text {Total GlcNAc }}$ \\
MSPS complete & 71 & $49 \cdot 2$ & 10 & 56 \\
MSPS without glucose & 63 & 47 & 50 & 50
\end{tabular}

* Measured after wall hydrolysis with a chitinase preparation [specific activity: 0.5 mg GlcNAc liberated (mg protein $\left.)^{-1}(24 \mathrm{~h})^{-1}\right]$.

(final concentration $100 \mu \mathrm{g} \mathrm{ml}^{-1}$ ) was either added to the medium prior to inoculation or applied to small areas on the periphery of the colony. Measurements of hyphae were made with a stage micrometer slide.

Growth in the presence of radioactive substrates. Duplicate cultures were grown for $4 \mathrm{~d}$ in liquid medium, harvested and washed under aseptic conditions, and then transferred to fresh medium with the appropriate additions of polyoxin $\mathrm{D},\left[{ }^{14} \mathrm{C}\right]$ glucose or $\left[{ }^{14} \mathrm{C}\right] \mathrm{GlcNAc}$. The cultures were grown in these media for different periods of time and then harvested. The $\left[{ }^{14} \mathrm{C}\right]$ glucose-grown cultures were washed twice with a $0.3 \%(\mathrm{w} / \mathrm{v})$ solution of unlabelled glucose and the $\left[{ }^{14} \mathrm{C}\right]$ GlcNAc-grown cultures were washed twice with a $0.3 \%$ (w/v) solution of unlabelled GlcNAc before washing with cold distilled water. The disappearance of radioactivity from the medium and the amount found in the mycelium were measured.

Extraction and analysis of the cell walls. The washed liquid-grown mycelia were frozen and homogenized in a VirTis homogenizer at high speed and then subjected to sonic treatment for 5 min intermittently at $20 \mathrm{kHz}$. In tracer experiments, small portions of the resulting suspensions were rapidly pipetted to scintillation vials containing $10 \mathrm{ml}$ dioxan scintillation fluid $(5 \mathrm{~g}$ 2,5-diphenyloxazole, $100 \mathrm{~g}$ naphthalene, and 1,4dioxan to 1 litre) and counted in a Beckman model LS 100 scintillation counter. The suspensions were centrifuged at $1000 \mathrm{~g}$ for $20 \mathrm{~min}$, the precipitate was resuspended in $20 \mathrm{ml}$ water and the whole procedure was repeated until the precipitate consisted exclusively of wall fragments, as indicated by cotton blue staining (Dietrich, 1975). Total insoluble protein (Lowry et al., 1951) and total carbohydrate (Umbreit, Burris \& Stauffer, 1964) were measured in the washed wall preparations. Radioactivity in labelled walls was determined by counting $2 \mathrm{mg}$ dried walls suspended in $10 \mathrm{ml}$ toluene scintillation fluid [4 $\mathrm{g} 2,5$-diphenyloxazole, 0.05 g 1,4-di-2-(5-phenyloxazolyl)benzene, and toluene to 1 litre].

The freeze-dried walls were subjected to acid hydrolysis as previously described (Dietrich, 1973, 1975) and to enzyme digestion using a chitinase (EC 2.4.1.16) preparation (Sigma) purified by affinity chromatography (Jeuniaux, 1957). This preparation did not release $N$-acetylglucosamine from glycoproteins or from hyaluronic acid, under the experimental conditions used. Walls $(5 \mathrm{mg})$ were incubated with chitinase $\left(10 \mu \mathrm{g} \mathrm{ml}^{-1}\right)$ at $30^{\circ} \mathrm{C}$ for $72 \mathrm{~h}$ with continuous shaking. Reducing sugars (Nelson, 1944), hexosamines (Blix, 1948) and 
$N$-acetylglucosamine (Reissig, Strominger \& Leloir, 1955) were determined in wall hydrolysates. Products were separated by paper chromatography (Chargaff, Levine \& Green, 1948) and thin-layer chromatography (Schimid, Kebrle \& Karrer, 1952), followed by staining with silver nitrate reagent (Trevelyan, Procter \& Harrison, 1950) or $0.2 \%$ (w/v) ninhydrin in acetone at $105{ }^{\circ} \mathrm{C}$. In tracer experiments, paper chromatograms were cut lengthwise into strips (corresponding to each chromatographed sample) and scanned in a Packard scanning apparatus. The regions corresponding to peaks in radioactivity were cut out and counted in toluene scintillation fluid.

\section{RESULTS}

Polyoxin D $\left(100 \mu \mathrm{g} \mathrm{ml}^{-1}\right)$ did not affect the radial growth of Achlya radiosa in agar medium. Microscopical observations indicated that there was an increase in hyphal diameter (Table 1) along main hyphae, although tip bursting did not occur. The addition of polyoxin $\mathrm{D}$ to cultures during growth in liquid medium resulted in an increase in dry weight and a decrease in wall weight of the mycelium. The walls of polyoxin D-treated mycelia produced less glucosamine than the controls (Table 1).

Polyoxin D promoted a slight increase in glucose incorporation from the medium during $24 \mathrm{~h}$ exposure of the mycelium to the antibiotic in the presence of $\left[{ }^{14} \mathrm{C}\right]$ glucose (not shown). It caused a decrease in the incorporation of $\left[{ }^{14} \mathrm{C}\right] \mathrm{GlcNAc}$ from the medium and a decrease in the incorporation of this compound into the cell wall (Table 2). Similar effects were observed if unlabelled glucose was present in the growth medium during the treatment.

Enzymic hydrolysis of the $\left[{ }^{14} \mathrm{C}\right] \mathrm{GlcN} A c-l a b e l l e d$ walls with chitinase showed that there was considerably less ${ }^{14} \mathrm{C}$ in walls from polyoxin D-treated mycelium (Table 2). The total amount of GlcNAc liberated by hydrolysis with chitinase was also lower in walls from polyoxin D-treated mycelium, as indicated by colorimetric determination of GlcNAc in these hydrolysates (Table 2). The identity of GlcNAc in wall hydrolysates was determined by paper and thin-layer chromatography, the latter being followed by autoradiography.

\section{DISCUSSION}

Polyoxin D promoted enlargement of hyphal diameters in Achlya radiosa although colony growth and tip integrity were not significantly affected by the antibiotic. Also, cultures grown in the presence of polyoxin D incorporated less $N$-acetylglucosamine in their walls than did untreated cultures.

Polyoxin D is a strong inhibitor of chitin synthesis and acts as a specific competitive inhibitor of chitin synthase in different fungi (Endo et al., 1970; Keller \& Cabib, 1971; Bartnicki-Garcia \& Lippman, 1972; Gooday, de Rousset-Hall \& Hunsley, 1976). The observation that it reduces the synthesis of an $\mathrm{N}$-acetylglucosamine-containing compound in the cell walls of $A$. radiosa constitutes further evidence for the suggested chitinous nature of this compound (Dietrich, 1973, 1975).

As previously observed by Isono et al., (1967), and shown here, polyoxin D does not inhibit growth of oomycetes to the same extent as that of higher fungi. Since the walls of the oomycetes are composed mostly of glucans (Bartnicki-Garcia, 1968; Sietsma, Eveleigh \& Haskins, 1969; Novaes-Ledieu, Jiménez-Martínez \& Villanueva, 1967), the inhibition of chitin synthesis by polyoxin D might not cause growth inhibition or the hyphal tip bursting effects observed in fungi known to contain chitin (Bartnicki-Garcia \& Lippman, 1972). It could, however, explain the enlargement of hyphal diameter. This effect suggests that the role of chitin in $A$. radiosa, and possibly in other oomycetes, may be related to the flexibility of the hyphae.

We thank Dr C. P. Dietrich for useful suggestions and the use of some of his laboratory facilities, and Professor F. Lara (University of São Paulo) and Professor Norman M. 
MacDuffie (University of Saskatchewan) for the supplies of $\left[{ }^{14} \mathrm{C}\right]$ glucose and $\left[{ }^{14} \mathrm{C}\right] \mathrm{GlcNAc}$, respectively.

This work was aided by grants from the Fundação de Amparo à Pesquisa do Estado de São Paulo (FAPESP), and Conselho Nacional de Desenvolvimento Científico e Tecnológico (CNPq), Brazil. G. M.A.C. is on leave of absence from the Instituto de Antibióticos, Universidade Federal de Pernambuco, under a fellowship from the Coordenação de Aperfeiçoamento de Pessoal de Nível Superior (CAPES), Brazil.

\section{REFERENCES}

Aronson, J. M. (1965). The cell wall. In The Fungi, vol. I, pp. 49-76. Edited by G. C. Ainsworth \& A. C. Sussman. New York: Academic Press.

BartNicki-Garcia, S. (1968). Cell wall chemistry, morphogenesis, and taxonomy of fungi. Annual Review of Microbiology 22, 87-108.

Bartnicki-Garcia, S. \& LIPPMAN, E. (1972). Inhibition of Mucor rouxii by polyoxin D: effects on chitin synthetase and morphological development. Journal of General Microbiology 71, 301-309.

BLIx, G. (1948). The determination of hexosamines according to Elson and Morgan. Acta chemica scandinavica 2, 467-473.

Chargaff, E., Levine, C. \& Green, C. (1948). Techniques for the demonstration by chromatography of nitrogenous lipid constituents, sulfurcontaining amino-acids, and reducing sugars. Journal of Biological Chemistry 175, 67-71.

Dick, M. W. (1969). Morphology and taxonomy of the Oomycetes, with special reference to Saprolegniaceae, Leptomitaceae, and Pythiaceae. II. Cytogenetic systems. New Phytologist $\mathbf{7 1}$ $1151-1159$.

Dietrich, S. M. C. (1973). Carbohydrates from the hyphal walls of some Oomycetes. Biochimica et biophysica acta 313, 95-98.

Dietrich, S. M. C. (1975). Comparative study of hyphal wall components of Oomycetes. Saprolegniaceae and Pythiaceae. Anais da Academia Brasileira de ciências 47, 155-162.

Endo, A., Kakiki, K., \& Misato, J. (1970). Mechanism of action of the antifungal agent polyoxin $\mathrm{D}$. Journal of Bacteriology 104, 189-197.

GoodAy, G. W. (1972). The effect of polyoxin D on morphogenesis in Coprinus cinereus. Biochemical Journal 129, 17-18P.

Gooday, G. W., de Rousset-Hall, A. \& Hunsley, D. (1976). The effect of polyoxin D on chitin synthesis in Coprinus cinereus. Transactions of the British Mycological Society 67, 77-83.

Isono, K., Nagatsu, J., Kobinata, K., SazaKi, K. \& Suzuki, S. (1967). Studies on Polyoxins, antifungal antibiotics. V. Isolation and characterization of Polyoxins C, D, F, F, G, H and I.
Agricultural and Biological Chemistry 31, 190199.

Jeuniaux, C. (1957). Purification of a Streptomyces chitinase. Biochemical Journal 66, 29P.

Keller, F. A. \& CABIB, E. (1971). Chitin and yeast budding. Properties of chitin synthetase from Saccharomyces carlsbergensis. Journal of Biological Chemistry 246, 4008-4016.

Lin, C. C. \& Aronson, J. M. (1970). Chitin and cellulose in the cell walls of the Oomycetes Apodachlya sp. Archiv für Mikrobiologie 72, 111-114.

Lin, C. C., Sicher Jr, R. C. \& Aronson, J. M. (1976). Hyphal wall chemistry in Apodachlya. Archives of Microbiology 108, 85-91.

Lowry, O. H., Rosebrough, N. J., Farr, A. L. \& RANDALL, R. J. (1951). Protein measurement with the Folin phenol reagent. Journal of Biological Chemistry 193, 265-275.

Nelson, N. (1944). A photometric adaptation of the Somogyi method for the determination of glucose. Journal of Biological Chemistry 153, 375-380.

Novaes-Ledieu, M., Jiménez-Martínez, A. \& Villanueva, J. R. (1967). Chemical composition of hyphal wall of Phycomycetes. Journal of General Microbiology 47, 237-245.

Reissig, J. L., Strominger, J. L. \& Leloir, L. F. (1955). A modified colorimetric method for the estimation of $\mathrm{N}$-acetyl-aminosugars. Journal of Biological Chemistry 217, 959-966.

Schimid, H., Kebrle, J. \& Karrer, P. (1952). Über Curarealkaloide aus Calebassen. Helvetica chimica acta 35, 1864.

Seymour, R. L. (1970). The genus Saprolegnia. Nova Hedwigia 19, 1-124.

Sietsma, J. H., Eveleigh, D. E. \& Haskins, R. H. (1969). Cell wall composition and protoplast formation of some Oomycetes species. Biochimica et biophysica acta 194, 306-317.

Trevelyan, W. E., Procter, D. P. \& Harrison, J.S. (1950). Detection of sugars on paper chromatograms. Nature (London) 166, 444-445.

Umbreit, W. W., Burris, R. H. \& Stauffer, J. F. (1964). Manometric Techniques, 4th edn, p. 210. Minnesota: Burgess. 